\title{
PERILAKU KONSUMEN TERHADAP E-COMMERCE DISAAT PANDEMI COVID 19 DI SHOP AND TRAVEL
}

\author{
Eri Mardiani ${ }^{1}$, Nur Rahmansyah ${ }^{2}$, Farid Al Rizky ${ }^{3}$ \\ Program Studi Informatika Universitas Nasional, Program Studi Animasi Politeknik Negeri \\ Media Kreatif, Program Studi Manajemen Universitas Siber Asia \\ Jl. Sawo Manila No. 61 Pasar Minggu Jakarta Selatan 12520, Jl. Srengseng Sawah Jagakarsa \\ Jakarta Selatan 12640, Jl.Harsono RM No.1 Ragunan Pasar Minggu Jakarta Selatan 12550 \\ erimardiani1@gmail.com,nur_rahmansyah@polimedia.ac.id, alrizkyfarid@gmail.com
}

\begin{abstract}
Abstrak Saat ini kondisi covid-19 sangat berpengaruh terhadap kehidupan bermasyarakat khususnya kondisi ekonomi, dikondisi pandemi covid-19 seperti ini masyarakat dihadapkan faktor resiko yang banyak untuk menghindari melakukan transaksi secara langsung guna menghindari penyebaran virus corona ini. Dan Masyarakat diharuskan menghindari kontak fisik (physical distancing) sehingga dalam melakukan transaksi masyarakat lebih banyak menggunakan transaksi secara digital. Dengan kondisi seperti ini akhirnya membuat masyarakat mulai melakukan transaksi secara online dimulai dengan berbanja online, karena untuk menghindari kontak fisik. Dan dampak positif bagi perusahaan atau usaha mengalami peningkatan yang signifikan terhadap penjualan dan pembelian produk perusahaan dampai dari kondisi pandemi covid ini, dan menyebabkan perusahaan untuk bisa beralih fungsi sistem penjualan dan pembeli dengan berbasis digital dan ini bisa dilihat dari pergerakan transaksi ecommerce yang sangat meningkat,transaksi pembelian meningkat secara drastis dampak pandemi covid 19 ini, serta penggunaan aplikasi belanja online mengalami peningkatan yang signifikan.

Kata Kunci : covid19, e-commerce, perilaku konsumen, Kim
\end{abstract}

\section{PENDAHULUAN}

Kondisi Indonesia saat ini dihadapkan bencana nasional pandemi covid 19, dilihat dari penyebaran covid 19 yang setiap harinya semakin meningkat dan covid 19 tidak hanya menyerang kesehatan namun ekonomi secara umum nya tak terkecuali di indonesia. Ekonomi di indonesia diprediksi hanya tumbuh sebesar 2,5 persen bahkan bisa mencapai 0 persen.[2]

Bagi perusahaan harus bisa memaksimalkan penggunaan e-commerce dan harus menjalani peraturan pemerintah untuk membatasi penggunaan uang tunai atau kertas, semua transaksi menggunakan online dan banyak nya pengurangan pegawai menjadi dampak penyebaran covid-19 ini[5].

Sebagian besar toko atau supermarket saat ini sudah banyak yang menyediakan layanan digital. Dari hasil survei Asosiasi Penyelenggara Jasa Internet Indonesia (APJII) Kita dapat melihat Jumlah pengguna internet Indonesia di 2020 menembus angka 196,7 juta orang pada 2020[1]. APJII dalam hasil surveinya mengungkapkan bahwa pengguna internet di Indonesia hingga triwulan kedua 2020 mencapai 73,7 persen naik dari 64,8 persen dari tahun 2018. Pertumbuhan e-commerce Indonesia di Tahun 2020 yang meningkat cukup banyak dibandingkan 2019. Dengan peningkatan 15 Juta Smartphone yang terkoneksi dan 25 Juta Pengguna Internet, hal ini mempertegas bahwa pentingnya visibilitas bisnis di Internet dengan menggunakan Strategi Digital Marketing.

Mengacu pada database perusahaan yang berdasarkan susunan / kumpulan data operasional lengkap dari suatu organisasi/perusahaan yang diorganisir / dikelola dan simpan secara terintegrasi dengan menggunakan metode tertentu, dengan menggunakan komputer, sehingga mampu menyediakan informasi yang optimal diperlukan pemakainya[4].

Peningkatan penjualan perusahaan sangat penting untuk keberlangsungan suatu usaha, maju dan mundurnya usaha dapat dilihat dari peningkatan penjualan secara online atau offline[6]. 


\section{METODE PENELITIAN}

Model yang digunakan dalam penelitian ini adalah model adopsi teknologi yang dikembangkan oleh KIM et.al, yaitu A trust-based consumer decision-making model[3]. Pemilihan model ini dilatarbelakangi oleh kondisi Shop and travel disaat pandemi covid 19 yang melihat perbandingan penjualan dengan menggunaka metode tradisional dengan online memiliki perbedaan yang sangat besar.

Pada Model Kim [3], terdapat dua variabel eksogen (variabel bebas/independen) yang memiliki pengaruh signifikan terhadap penggunaan teknologi komputer. Kedua variabel tersebut adalah Trust (kepercayaan yang dimiliki individu akan mempengaruhi untuk melakukan transaksi secara online), Benefit (Manfaat yang didapat oleh konsumen lebih besar jika melakukan transaksi online. Gambar 1 merupakan model penelitian yang digunakan dalam penelitian ini.

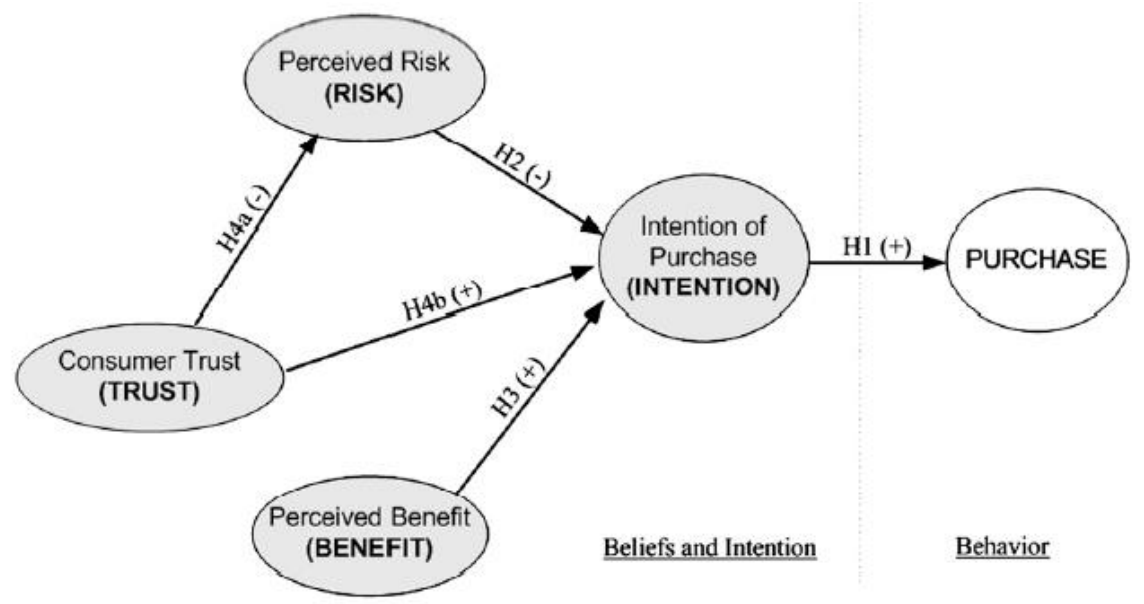

\section{Gambar 1 Model Penelitian[3]}

Berikut adalah definisi dari setiap variabel penelitian yang dibuat berdasarkan model Kim :

1). Trust merupakan sifat yang melekat pada belanja internet, kepercayaan merupakan salah satu strategi untuk menyakinkan dengan pasti dan terkendali dimasa depan.

2). Benefit merupakan salah satu yang dirasakan konsumen terhadap keyakinan mereka terhadap transaksi online pada situs shop and travel

3). Risk sebagai salah satu yang dirasakan konsumen terhadap keyakinan mereka pada transaksi online di situs shop and travel

4). Intention dipengaruhi oleh persepsi manfaat, resiko dan kepercayaan terhadap pihak penjual.

5). Purchase merupakan variabel yang menyatakan bahwa pembelian akan dilakukan oleh pengguna pad web shop and travel.

Pada penulisan ini adalah mengacu pada Model Kim[3] dalam menentukan analisa kepercayaan dan Niat Pembelian e-Commerce pada Shop and travel.

Dalam menentukan tingkat kepercayaan tersebut, penelitian ini menggunakan 5 variabel yaitu Kepercayaan (Trust), Resiko (Risk), Manfaat (Benefit), Niat Pembelian (Intention) dan Pembelian (Purchase).

Model Kim[3] menjelaskan perilaku konsumen membuat keputusan pembelian berdasarkan niat pembelian. Niat pembelian dipengaruhi oleh persepsi manfaat, resiko dan kepercayaan terhadap toko tersebut. Konsumen akan lebih mungkin terlibat dalam pembelian melalui Internet ketika resiko dirasakan rendah, manfaat dirasakan adalah tinggi dan ketika kepercayaan tinggi (efek langsung) maka kepercayaan para konsumen terhadap penjual juga akan meningkatkan niatnya untuk membeli secara tidak langsung

Dalam model ini dapat dibuat suatu pengaruh antar variabel sebagai berikut:

1. Kepercayaan berpengaruh terhadap Resiko

2. Kepercayaan berpengaruh terhadap Niat Pembelian

3. Resiko berpengaruh terhadap Niat Pembelian 
4. Manfaat berpengaruh terhadap Niat Pembelian

5. Niat Pembelian berpengaruh terhadap Pembelian

Pada penelitian ini kerangka pemikiran menggunakan pengaruh antar variabel dengan menggunakan teori model Kim yaitu Kepercayaan (Trust), Resiko (Risk), Manfaat (Benefit), Niat Pembelian (Intention) dan Pembelian (Purchase).

Kerangka pemikiran tersebut dapat dilihat pada gambar berikut ini:

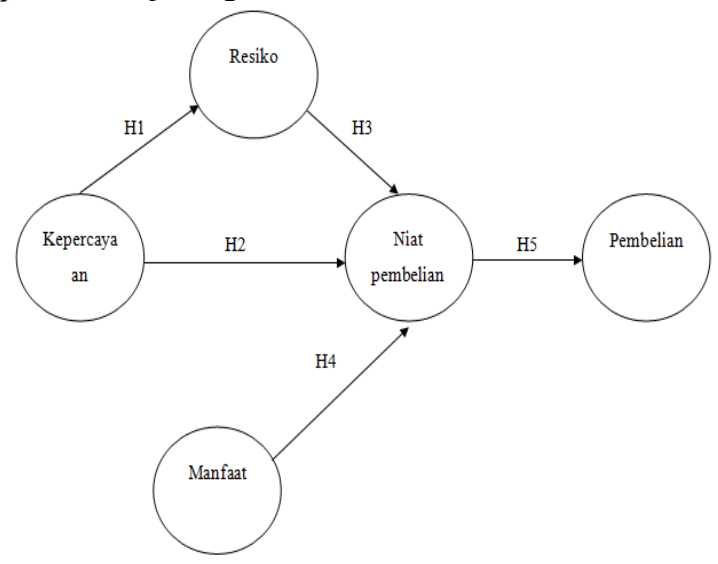

\section{Gambar 2. Kerangka Pemikiran}

Berdasarkan kerangka pemikiran diatas, maka disusunlah hipotesis sebagi berikut:

H1 : Diduga Kepercayaan (Trust) mempunyai pengaruh negatif secara langsung terhadap Resiko (Risk)

H2 : Diduga Kepercayaan (Trust) mempunyai pengaruh positif secara langsung terhadap Niat Pembelian (Intention)

H3 : Diduga Resiko (Risk) mempunyai pengaruh negatif secara langsung terhadap Niat Pembelian (Intention)

H4 : Diduga Manfaat (Benefit) mempunyai pengaruh positif secara langsung terhadap Niat Pembelian (Intention)

H5 : Diduga Niat Pembelian (Intention) mempunyai pengaruh positif secara langsung terhadap Pembelian (Purchase)

\section{HASIL DAN PEMBAHASAN}

Berdasarkan modifikasi model gambar 1 dan 2, maka dapat dijelaskan bahwa model yang didapatkan pada penelitian akhir adalah sebagai berikut :

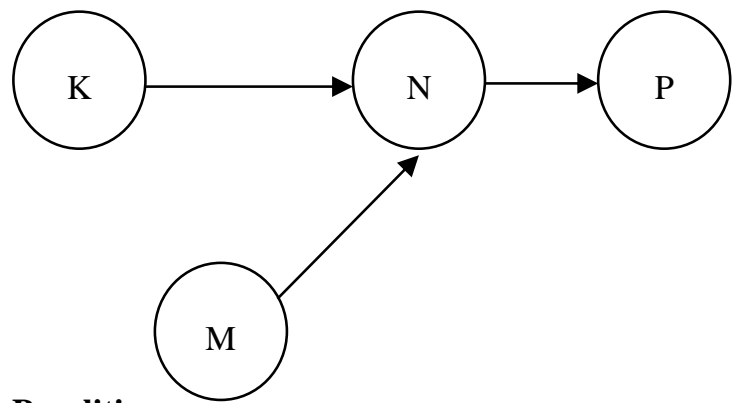

\section{Gambar 3. Model Akhir Penelitian}

Overall model fit statistik memberikan nilai Chi-square $=0.625$ dengan probabilitas $=0.732$ yang berarti model sangat baik. Dari gambar 3 dapat disimpulkan bahwa kepercayaan(K) berpengaruh positif terhadap Niat Pembelian(NP) dengan koefisien standardized 0.253, begitu juga dengan Manfaat(M) berpengaruh postif terhadap Niat Pembelian(NP) dengan koofisien standardized 0.289 sedangkan nilai latent Niat Pembelian untuk intercepts 
sebesar 7.642. Niat Pembelian(NP) juga berpengaruh positif terhadap Pembelian(P) dengan koofisien standardized 0.241 sedangkan nilai latent Pembelian untuk intercepts sebesar 4.412.

Tabel 1. Koefisien Standar Model Akhir

\begin{tabular}{l} 
Standardized Regression Weights: (Grou number I - Default model) \\
\hline
\end{tabular}

Tabel 2. Intercepts Model Akhir Intercepts: (Grou number 1 - Default model)

\begin{tabular}{|l|rrrrr|}
\hline & Estimate & S.E. & C.R. & P & Label \\
\hline NP & 7.642 & 1.396 & 5.472 & $* * * *$ & par_6 \\
P & 4.412 & .777 & 5.679 & $* * * *$ & par_7 \\
\hline
\end{tabular}

Sehingga persamaan struktural untuk menyatakan hubungan kausalitas dapat dinyatakan sebagai berikut:

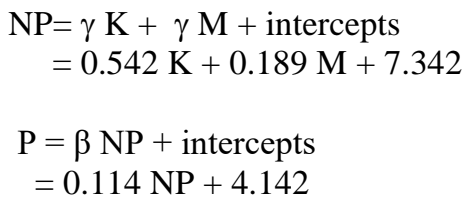

Dari gambar 3 dapat dijelaskan bahwa variabel Kepercayaan (K) berpengaruh terhadap Niat Pembelian (NP). Semakin tinggi tingkat kepercayaan (K) maka responden akan semakin kuat niat pembeliannya untuk melakukan transaksi online pada Shop and travel

Variabel Manfaat (M) berpengaruh terhadap Niat Pembelian (NP). Semakin tinggi tingkat Manfaat(M) yang dirasakan oleh responden maka responden akan semakin kuat niat pembeliannya untuk melakukan transaksi online pada Shop and travel

Variabel Niat Pembelian (NP) berpengaruh terhadap Pembelian (P). Semakin tinggi Niat Pembelian(NP) untuk melakukan transaksi online maka responden akan semakin kuat untuk melakukan pembelian transaksi online pada Shop and travel

Kemanfaatan yang diperoleh dari penggunaan model ini antara lain meningkatkan kepercayaan masayarakat dan memberikan rangsangan terhadap responden atas manfaat yang didapat jika melakukan transaksi online di Shop and travel, meyakinkan responden untuk mempunyai niat yang kuat untuk melakukan transaksi online .

\section{KESIMPULAN}

Kesimpulan dari penelitian ini menunjukkan bahwa masyarakat di pandemi covid 19 seperti ini harus mengikuti himbauan pemerintah agar menghidari transaksi secara langsung dalam segala bidang khusus penjualan yaitu dengan lebih banyak melakukan transaksi dengan menerapkan penggunaan internet. Dampak bagi sektor bisnis sebagai media perantara dalam melakukan transaksi berbelanja online yaitu e-commerce, sangat berpengaruh sekali dan dapat dilihat dari manfaat dan dampak positip itu dilihat dengan penggunaan variabel kepercayaan, niat pembelian, sikap, manfaat untuk melakukan pembelian dalam transaksi e-commerce. Masyarakat atau responden sangat antusias melakukan pembelian dengan menggunakan transaksi e-commerce secara signifikan karena memudahkan bagi masyarakat sebagai pembeli maupun sebagai penjual dalam mendapatkan informasi mengenai yang dibutuhkan maupun melakukan transaksi serta memberikan kepuasan pada pelayanan nya. 


\section{DAFTAR PUSTAKA}

[1] https://databoks.katadata.co.id/datapublish/2020/11/11/jumlah-pengguna-internet-di-indonesia-capai-1967juta

[2] https://www.merdeka.com/uang/virus-corona-terjadi-6-bulan-daya-beli-masyarakatterpukul-palingberat.html)

[3] Dan J. Kim, Donald L. Ferrin, H. Raghav Rao. 2008. January 2008, Pages 544-564. A trust-based consumer decision-making model in electronic commerce: The role of trust, perceived risk, and their antecedents, https://www.sciencedirect.com/science/article/abs/pii/S0167923607001005

[4] Mardiani, Eri, Nur Rahmansyah, Hendra Kurniawan, Dana Indra Sensuse, Jayanta. 2016. Kumpulan Latihan SQL, Jakarta : Elex Media Komputindo

[5] Mardiani, Eri, Nur Rahmansyah, Surniawan, Imam Budiawan, Muchammad Sholeh. 2016. Aplikasi Penggajian Menggunakan Visual Basic, MySQL dan Data Report, Jakarta : Elex Media Komputindo

[6] Mardiani, Eri, Nur Rahmansyah, Hendra Kurniawan, Anita Muliawati, Dwi Sidik Permana. 2017. Membuat Aplikasi Penjualan Menggunakan Java Netbeans, Mysql, dan iReport, Jakarta : Elex Media Komputindo

[7] Surniawan, Eri Mardiani, Nur Rahmansyah dan Yuni Widiastiwi. 2013. Kumpulan Latihan Visual Basic, Jakarta : Elex Media Komputindo 